Boise State University

ScholarWorks

$1-1-2015$

\title{
Grassroots Outreach to Foster a Diverse Community
}

Elizabeth Ann Ramsey

Boise State University 


\section{Innovative Solutions for Building Community in Academic Libraries}

Sheila Bonnand

Montana State University, USA

Mary Anne Hansen

Montana State University, USA

A volume in the Advances in Library and Information Science (ALIS) Book Series

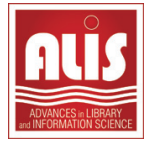

Information Science
REFERENCE

An Imprint of IGI Global 
Managing Director:

Managing Editor:

Director of Intellectual Property \& Contracts:

Acquisitions Editor:

Production Editor:

Development Editor:

Typesetter:

Cover Design:
Lindsay Johnston

Austin DeMarco

Jan Travers

Kayla Wolfe

Christina Henning

Caitlyn Martin

Cody Page

Jason Mull

Published in the United States of America by

Information Science Reference (an imprint of IGI Global)

701 E. Chocolate Avenue

Hershey PA, USA 17033

Tel: 717-533-8845

Fax: 717-533-8661

E-mail: cust@igi-global.com

Web site: http://www.igi-global.com

Copyright (C) 2015 by IGI Global. All rights reserved. No part of this publication may be reproduced, stored or distributed in any form or by any means, electronic or mechanical, including photocopying, without written permission from the publisher. Product or company names used in this set are for identification purposes only. Inclusion of the names of the products or companies does not indicate a claim of ownership by IGI Global of the trademark or registered trademark.

Library of Congress Cataloging-in-Publication Data

Innovative solutions for building community in academic libraries / Sheila Bonnand and Mary Anne Hansen, editors.

pages $\mathrm{cm}$

Includes bibliographical references and index.

ISBN 978-1-4666-8392-1 (hardcover) -- ISBN 978-1-4666-8393-8 (ebook) 1. Academic libraries--Management. 2. Community development. I. Bonnand, Sheila, editor. II. Hansen, Mary Anne, 1961- editor.

Z675.U5I576 2015

025.1'977--dc23

2015008169

This book is published in the IGI Global book series Advances in Library and Information Science (ALIS) (ISSN: 23264136; eISSN: 2326-4144)

British Cataloguing in Publication Data

A Cataloguing in Publication record for this book is available from the British Library.

All work contributed to this book is new, previously-unpublished material. The views expressed in this book are those of the authors, but not necessarily of the publisher.

For electronic access to this publication, please contact: eresources@igi-global.com. 


\title{
Chapter 12 \\ Grassroots Outreach to Foster a Diverse Community
}

\author{
Elizabeth Ann Ramsey \\ Boise State University, USA
}

\begin{abstract}
This exploration of an academic library's outreach efforts presents a broad overview of a range of initiatives aimed at fostering interaction with library staff and resources. These efforts are put forth by a variety of contributors from throughout the library's staff without a management mandate or day-to-day control. Although these grassroots outreach efforts cost little to nothing, they still act to effectively inculcate a campus-wide perception of the library as a forward-thinking, inclusive and supportive institution while generating a welcoming atmosphere for diverse users. This atmosphere in turn fosters a learning and research community that sees the library as an important contributor to its success. This chapter describes the foundations for this type of outreach as well as giving examples of a number of innovative methods Albertsons Library at Boise State University uses to provide meaningful opportunities for its users to interact with staff, services and resources in a way that cultivates a feeling of inclusion in the community.
\end{abstract}

\section{INTRODUCTION}

Albertsons Library at Boise State University serves a campus of more than 22,000 students, nearly 2,700 faculty and staff, and the local community, as residents of Idaho state are afforded borrowing and limited computer access at the library. The University currently offers 21 certificate programs, 98 associate and baccalaureate degrees, 82 graduate degrees, and nine doctorate degrees. Although a majority of the student body (79\% according to Boise State's Facts \& Figures, 2013-2014) hails from largely monoculture Idaho, the demographics on campus are slightly more diverse. According to the 2010 census, the Idaho population was $89 \%$ white, while the Boise State campus was $76 \%$ white in 2013-2014. Additionally, the campus population is more culturally diverse than the state's; international students make up 3\% of the student body, with the majority of those students coming from Saudi Arabia, Kuwait, Canada, China, India and Nepal. However, that relatively low statistic does not include the refugee population

DOI: 10.4018/978-1-4666-8392-1.ch012

Copyright $\odot$ 2015, IGI Global. Copying or distributing in print or electronic forms without written permission of IGI Global is prohibited. 
on campus or other naturalized citizens. Further evidence of diversity on campus might be found in Boise State support programs such as the College Assistance Migrant Program (CAMP), the Center for Multicultural and Educational Opportunities, the Disability Resource Center, and the Lesbian, Gay, Bisexual, Transgender, Queer, Intersex, and Ally (LGBTQIA) space and events at the Women's Center.

The library at Boise State was dedicated as Albertsons Library in 1995 after Albertsons, Inc. donated six million dollars toward the library expansion. The library staff includes 37 classified and professional staff, 20 tenure track librarians, and student workers in approximately 60 positions. The library's overarching mission is to actively engage in learning, teaching, and research at Boise State University. Towards that mission, Albertsons Library's provides access to resources including: more than 620,000 print books, 119,000 electronic books, and more than 300 databases, with the growth of the electronic collection steadily outstripping that of the print in numbers and cost.

The economic realities of providing access to electronic resources leaves many academic libraries with few funds to allot to outreach efforts. This has certainly been the case for Albertsons Library at Boise State University, which has had no money regularly budgeted for outreach or marketing for years. Also, since about 2006 Albertsons has had little regular programming to speak of and has initiated no print marketing beyond bookmarks and that required by a logo change at Boise State in 2013. Still, through a determined service orientation, active participation at cultural and professional development events, the creation of various no-cost activities and displays, and a creative use of social media, Albertsons Library has positioned itself as a leader in the support of the university research and learning communities.

The library has achieved this position through outreach efforts which are not confined to a committee or other specially designated group. Instead, students, faculty, and classified and professional staff all contribute in a grassroots effort to build community while fostering the library brand as a progressive institution dedicated to supporting the success of diverse users. This chapter will show how this grassroots mode of outreach, while less structured than most standard outreach programs, has been quite successful in connecting to and engaging a community that extends beyond campus.

Although this overview asserts the success of the library's grassroots outreach programs, it must be noted that one drawback to the grassroots outreach activities outlined in this chapter is that its spontaneous nature does not often afford formal assessments. Still, sufficient positive responses have been noted (see Assessments) that Albertsons Library will continue this flexible and responsive form of outreach in addition to contemplating more strategic and measurable methods of outreach and assessment (see Future Directions).

\section{BACKGROUND}

In their research Carter \& Seaman established a working definition of outreach in two parts: services such as reference, research consultations, library resources and the library space, and promotion of those services (2011). This definition is quite applicable to Albertsons Library, for which outreach encompasses activities in circulation, reference, instruction, collection development and liaison work as well as the more traditional programming and marketing. In other words, for Albertsons Library, outreach is anything that fosters engagement by the community to participate actively in the library.

This wide-ranging definition of outreach may have developed in part through a service orientation that permeates all aspects of librarianship at Albertsons Library. This orientation was articulated in a 2011 panel presentation by library management, 55,000 Ways to Say Yes: Customer Driven Acquisitions 
and More! The presentation outlined the library's dedication to not only timely, accurate acquisitions, but also exploring mobile technologies, and fostering personal connections (Cooper, Glackin, Moody). Research confirms that establishing this sort of service-oriented organizational culture can be key in establishing positive perceptions of libraries (Kaarst-Brown, Nicholson, Von Dran \& Stanton, 2004).

Students, staff and faculty at Albertsons Library contribute to this organizational culture of service by performing outreach as a natural part of their day-to-day work rather than at management's behest. Those participating in outreach at the library consistently focus on making users feel supported and welcome as a foundation to their continued engagement with library resources and space. By positioning the library as a supportive place for studying, socializing or simply resting, Albertsons Library feeds the learning community of the campus as a whole, establishing itself as the kind of place delineated by Watson as "essential to the lives of twenty first century learners" (2010, p.45).

Of course, a dedication to serving a library's users can be an effective starting point for outreach, but the library's staff must also be empowered to try new ideas freely. The chapter section, Empowering Staff Contributions, outlines various professional development activities that have helped the Albertsons Library's staff gain skills to effectively create engaging opportunities for library users. Baldwin found that when staff is trusted by management to have the best interests of the library at heart and to act in a professional manner, creativity is enhanced (1996). Lockhart \& Mahal tout the additional benefits of staff training, "Users can only benefit from well-educated staff who have a positive attitude toward continuing education... which will surely enhance the user experience" (2012, p.3). Barber noted that staff training and involvement make all the difference in building a positive reputation, increasing a library's ability to take advantage of word-of-mouth marketing (2014).

Perhaps one of the most vital aspects of staff training in this era of increasing diversity on college campuses is cross-cultural skill building. Montiel-Overall provides a framework to understand the importance of this type of training in accomplishing the general mission of the library profession (2009). Generally, by seeking better understanding of unfamiliar cultural groups, those involved in outreach can improve their intercultural skills, recognizing differences in learning and communication styles. For Hickock, understanding the prior library experiences of international students is essential when considering outreach opportunities to this segment of the library community (2011). Without intercultural training Mestra found evidence of a range of negative effects on library service including a lack of sensitivity and respect as well as an "inability to understand how culture affects library use" (2010, p.480). Conversely, by improving cross-cultural competence, outreach participants are more likely to create displays, programs and other activities that speak to a broad and diverse patronage.

Staff training may also help outreach contributors make the most of social media by enhancing their confidence in their ability to use these tools (Chu \& Du, 2013) as well as the ability to speak according to institutional guidelines or in the institutional "voice" (Solomon, 2011, p.29). The chapter section, Making the Most of Social Media, examines how Albertsons Library has developed a social media persona, or voice, which helps promote the library as a fluid, progressive institution tuned into the campus zeitgeist. This persona is described in social media guidelines on a shared web site, and fostered through the analysis of interactivity generated by social media posts. More than one person contributes to each social media network at Albertsons; however, by speaking through the established library persona, cohesive and coherent content is produced that speaks to users' interests and needs.

The persona in use for Albertsons social media accounts is an extension of the library's overall brand. For this chapter, branding is defined as the establishment of a subconscious association between a product or institution and certain characteristics. Singh described branding as an essential issue for 
libraries in that the brand is "a personification of the total offering of an organization or product and its value and contribution, to both the organization and the customer (2004, p.94). As a natural outgrowth of its service orientation and day-to-day outreach activities, Albertsons has promoted an image of the library as responsive, collaborative, and dedicated to the support of its learning and research community, as evidenced in the OUTREACH OVERVIEW sections of this chapter.

Equally important to establishing a library brand, and extending that brand through outreach efforts such as social media, is listening to the voice of users. Crawford refers to "listening" on social media networks as an important corollary to having a "voice" in that it "invokes the more dynamic process of online attention, and suggests that it is an embedded part of networked engagement" (2009, p.527) Salomon believes that paying attention to what users are saying on social media can help in analyzing their needs, as well as being a useful assessment of student satisfaction with the library when used with more quantitative measures (2013). However, by not just listening, but responding to what is being said on social media channels quickly and honestly, relationships can be formed that translate into brand loyalty (Kirk, 2011).

Albertsons Library's social media networks are directly tied to other outreach initiatives in the library, which have been developed to catch users' attention as they access the library space and resources. These initiatives are examined in the chapter section, Creating a Welcoming Atmosphere. The tie-in between social media, slide shows, signage and book displays are accomplished through a shared Google calendar that notes themes and key dates for each month and a web site which contains goals, purpose, guidelines and best practices for the various social media networks. The shared calendar and web site encapsulate most of the strategy and planning that the library's grassroots outreach have required. Although much of the literature on academic library outreach is adamant in its recommendations for detailed organization (Duke \& Tucker, 2007; Hallmark, Schwartz, \& Roy, 2007; Steiner, 2012), Albertsons Library has found that limiting its planning affords a freedom to innovate and respond in the moment.

This freedom allows library staff to grab opportunities to interact with the learning and research community outside the library as chances present themselves. These efforts are outlined in the chapter section, Becoming a Familiar Face. Rudin (2008) sees this sort of "roving librarianship" as essential to the establishment of academic libraries' value to a campus (2008, p.71). Like many academic libraries, the library participates in numerous planned campus events dedicated to informing users about resources, such as orientations and information fairs. However, by actively seeking out opportunities to switch roles, such as attending activities in which students are acting as the informants, the Albertsons library staff gains new insight into a huge segment of their user population, while inculcating an image of librarians as actively interested in student initiatives. Engaging with students at these events can also create what Wilcox referred to as "sticky relationships", the sorts of relationships that result in ongoing interactions between users with their libraries, "crucial to creating awareness of the library's resources and services" (2012, p.176).

Albertsons Library is also active at a number of student-sponsored events focused on multicultural awareness. Through participation in these workshops and presentations, Albertsons not only fosters engagement with library staff, space and resources, but also demonstrates a shared commitment with the Boise State campus to diversity and multicultural awareness. Lazzaro, Mills, Garrard, Ferguson, Watson, \& Ellenwood concluded that students, staff and faculty were made to feel more welcome at the 
library once they saw librarians attending diversity events and training (2014). In addition, Brinks \& Weinstein-Yates recommended attendance at cultural or thematic programs as an "excellent way to get the library connected with students' extracurricular activities and interests" (2008, p.148).

Staff at Albertsons Library also participates regularly in campus programs sponsored by or for Boise State's classified and professional personnel such as the Association of Classified Employees (ACE) programs, charity events and fundraisers. This kind of outreach helps create relationships between Albertsons Library and a segment of the campus community that may not always be targeted in traditional outreach efforts. Carter's research notes that, by reaching out to non-academic departments, librarians can foster relationships outside the traditional research mode which can garner institutional support and invitations to additional opportunities (2007).

Other, perhaps less obvious forms of outreach, are performed at Albertsons Library through engaging in partnerships with faculty outside traditional liaison roles, collaborating on committees and other gatherings focused on campus initiatives. Hernas \& Karnas confirmed that by actively participating in activities such as shared governance, librarians were able to form more substantial and rewarding relationships with other faculty (2008). Albertsons has found that the partnerships described in the chapter section, Collaborating for Understanding, can be quite powerful in helping alter perceptions of library faculty from clerical support staff to scholars who are actively engaged in the research community.

Altering faculty perceptions of the library is one part of a wider reaching change advocated by Stebelman, Siggins, Nutty, \& Long, who stated that academic libraries can best communicate their relevance on campus by changing stakeholders' images of libraries generally, "from that of a repository of information to that of an organization that advocates and exemplifies the use of cutting-edge technology in support of the university's mission" (1999, p.126). Virtue \& Espara delineate ways in which academic libraries can lead the way in instructional technology by helping faculty identify technologies that will best suit their needs and learn how to use these technologies in their research and instruction (2013). Librarians at Albertsons have done so through demonstrations of mobile technology, e-books and embedding digital media in online courseware at faculty workshops and seminars.

Albertsons Library has also found that assisting faculty in navigating the latest issues in scholarship, such as digital rights management, mobile technology, and data management requirements, helps faculty look to the librarians as peers to seek out for future collaborations and recommend to their fellow faculty members. The importance of this transformation in the image of academic libraries/librarians has been noted repeatedly in recent research. Monroe-Gulick, O'Brien \& White found this kind of transformation in faculty perceptions of an academic library to be key in establishing the library's value to a campus (2013). Jaguszewski \& Williams also confirmed the importance of developing these collaborative relationships in positioning libraries as a central and primary part of a university campus. Further, Meulemans \& Carr proposed that establishing genuine partnerships with faculty is essential to the accomplishment of the teaching and learning at the heart of the mission for most academic libraries (2013).

By engaging in the pursuit of common goals with its community, Albertsons Library has formed genuine partnerships that inform the library, and ground the library's grassroots outreach efforts in an understanding of user needs. As a result of forming purposeful relationships with its community, Albertsons Library is now "invited to participate in faculty/campus undertakings, considered a credible partner in campus and scholarly endeavors, engaged with the academic life of students and faculty, and referenced in communications across the campus" (Kranich, Lotts \& Springs, 2014, p.184). 


\section{OUTREACH OVERVIEW}

\section{Empowering Staff Contributions}

Albertsons Library uses a variety of methods to develop not only staff motivation to reach out to diverse communities, but also the informed perspectives to reach out effectively. In-house training has included concepts in cross-cultural competence, team building, and effective communication. For example, a professor in Boise State's department of nursing and author of Creating and Sustaining Civility in Nursing Education, presented at a meeting of all library staff to help foster civility as a part of Albertsons' intra- and inter-institutional service orientation. Representatives from across the campus are also invited to staff meetings to speak on Boise State initiatives in social media, student retention, career counseling, and more.

Further learning opportunities for Albertsons Library's staff are afforded by Boise State's Center for Teaching and Learning (CTL), which sponsors workshops and events in support of best practices in many aspects of instruction and community engagement. Instructional design consultants in the Academic Technologies department offer workshops and consultations on implementing technology and learning strategies in course design. Both faculty and staff are also encouraged to make use of the wide number of webinars available for more specialized training in library resources and services, and share their knowledge of new developments such as the new portfolio software being used on campus, Digication.

In addition to more formal training opportunities, Albertsons Library staff also learn from each other about special projects and accomplishments, showcasing their work through presentations to colleagues on topics from local library history to data management. When a team of library faculty completed the extensive development of an online course in information literacy they presented it to all library staff. When a professional staff member in special collections completed a digitization project of Boise State football game footage, he invited everyone at the library to its presentation. As an instructional designer at the library worked through his dissertation on the use of humor in instruction, he shared some of his findings and applicable methodology at a meeting open to all library instructors. These sorts of presentations help those at Albertsons Library gain an understanding and appreciation of how everyone contributes to the library mission, adding to their ability to participate in outreach activities that cross departmental boundaries.

Albertsons Library has also empowered its entire staff through its decision to provide iPads for all, regardless of the person's position at the library, "As we observe one another using iPads in ways we individually had not imagined, we are gaining a new respect, awareness, and appreciation for each other's skills and abilities, regardless of the position or rank of the user" (Aagard, Armstrong, Cooper, \& Nuxoll, 2013, p.20). The library did not simply hand over the iPads, but also offered training support in the form of meetings where all were welcome to share their favorite apps, and a web site where everyone could post questions, answers, and ideas for best practices. Through this simple, yet far-reaching decision, Albertsons Library has also effectively broken down silos of responsibilities in that all at the library can now address at least basic questions about mobile technology or engage patrons with library resources wherever they may meet them.

A further learning opportunity was presented to Albertsons Library in the form of a mandate from the Idaho State Board of Education requiring all state institutions to assess and rate their programs and services. This mandate came down in the fall of 2013, shortly after the new dean at Albertsons Library came on board. The dean took this opportunity to include personnel from all departments in the library 
on a committee which assigned components of library resources and services into various areas. As each area was complete it was presented to the library staff at large for comments and suggestions. The prioritization procedure provided a picture to all involved of how the library uses its services and resources in accomplishing its mission as well as contributing to the university strategic plan and accreditation efforts.

\section{Making the Most of Social Media}

With its flexibility, assessment tools, and cross-promotional possibilities, social media is a marketing dream for any institution with a limited marketing budget. Social media has certainly been the linchpin of Albertsons Library's outreach success. However, it does come with caveats in that social media has to address user needs, be done authentically and consistently, and be assessed regularly for its usefulness.

The development of Albertsons Library's award-winning use of social media began in 2006 when the library blog and Twitter account were started. The librarian who initiated these accounts also inculcated the library persona into the library's social media networks, a persona that is tuned into interactions with users, and highly aware of culture, memes, and issues of significance to followers. Since then the library's social media network has expanded to include Facebook, Pinterest, YouTube and Instagram, with participation open to anyone on the library staff with the passion to contribute and an understanding of the Albertsons Library social media persona.

In the fall of 2013 student workers at the library were trained to post on Facebook for the first time. They reviewed the library's guidelines for posting on social media and then submitted some sample posts for approval. In the eight months since the students began posting, Albertsons Library's Facebook page "likes" grew by over 20\%, strong evidence of the importance of student participation in the library's outreach efforts. A student worker from Afghanistan has been a key player in that growth, posting pictures of herself and friends using the library, and encouraging her friends to like the page. Although some librarians were concerned about the change in tone on the library's Facebook page from research and factual posts to more socially oriented posts, it was decided that students feeling welcome to extend their social selves into library social media was a measure of the relevance of the library to the students, and thus, an indicator of success. This decision was bolstered when two students got engaged in the library and the picture of their engagement on Albertsons' Facebook page topped 5,000 views within a few days.

Another social media network, Pinterest, was first launched by the library in 2013. Albertsons' Pinterest boards have mainly focused on items from Special Collections, with those collections that have yet to be digitized as a priority source for material. Interest has been keen in the Historic Boise State and Historic Boise Gear boards, but interactivity has not been as consistent as on other social media sites. It has also been noted that interactivity on the library's Instagram account has also been down in the past year, so these accounts may eventually be discontinued. By monitoring numbers of users and their interactivity on its social media networks, Albertsons can make better informed choices about which accounts to focus on, closing some, such as Flickr, for good, or piloting others, such as SoundCloud. The ephemeral nature of social media requires this sort of flexibility for ongoing success. It might also be noted that when a library chooses to participate in more than one social media network they must be aware of varying cultures and uses between the networks, as each social media community has differing expectations of communication. (Solomon, 2011).

Social media at Albertsons Library has been an important avenue of interaction with the university's non-traditional population. Students who come from other cultures may not have traditions of using the library or its resources. Returning students or first generation students may be intimidated by the tech- 
nology requirements of modern research. However, social media can be an important avenue to reach these groups. Lenhart, Purcell, Smith, \& Sickuhr reported that, "Fully 72\% of online 18-29 year-olds use social networking websites, nearly identical to the rate among teens" (2010, p.3). By speaking to students where they often live, in social media space, the library, its staff and its resources can become more familiar to non-majority groups, and perhaps even be seen as an ally.

The Outreach Coordinator for Albertsons Library has discovered an important avenue to building relationships with international students on social media through the Culture, Language and Identity conference, which is hosted each semester by learners of English at Boise State. During the conference in spring 2014, students presented on their positive experiences with Twitter, the coordinator took advantage of the Q\&A session after the presentation to speak up about the library's Twitter account, which resulted in new followers from the conference presenters. Through a presentation at the spring 2013 meeting of the same conference this librarian learned of a video created by Muslim women on wearing the hijab (head scarf), and got permission to post the video on the library's Facebook page. The video remains one of the most popular posts ever with over 5,000 views and numerous comments and shares.

\section{Creating a Welcoming Atmosphere}

The thoughtful use of the library space at Albertsons is yet another aspect of its success in engaging members of the learning and research communities with the library. The building is not cluttered with a lot of signage; instead, the library often relies on a slide show which plays on a monitor in the lobby as well as on all computers in the library to catch patrons' attention as they use the library space and resources. The slide content is frequently tied into themes which are also used in social media, helping coordinate a look and feel that helps establish the library brand. Images as well as themes are carefully curated to reflect the diversity of library users and speak to as wide a range of interests as possible. The themes are always tied into library resources and services, so, International Ninja Day is used to promote resources on body movement in the library's kinesiology library guide, National Jazz Appreciation Month promotes the Gene Harris Jazz Festival collection in the library's archives and National Novel Writing Month promotes the Western Writers collection in the library's institutional repository, ScholarWorks.

Book displays are also arranged in coordination with slide and social media themes, and, as mentioned in the Background section, are considered part of the library's outreach efforts to engage users with library resources. When Albertsons Library hosted an art exhibit for the campus event Act Now (a series of events geared toward building community with an awareness of human rights) the library also featured news about the exhibit in social media, in a slide, and in a book display of resources related to ethnic and gender studies. Although this effort took some coordination, it also works on the fly, as when a local school district removed Sherman Alexie's "The Absolutely True Diary of a Part-Time Indian" from their curriculum. Within 24 hours Albertsons Library had put together a book display of the banned book and other works by Alexie, taking a picture of the display and featuring it on social networks. These small displays, featured at the front of the library, are easy to put together and regularly result in circulation of items in the display. While engaging the users with library resources, these book displays are also symbolic of the library's attention to its community and its interests.

The library lobby is also home to Access (Circulation) Services, where staff have initiated a number of activities which catch users' attention in the library while fostering a feeling of fun and connectedness to patrons. Activities have included posting a large sheet of paper with a question, such as "What's your favorite research app?" or "What's the last good book you read?" with markers nearby to facilitate 
users' answers. The replies to these questions were featured in social media, and, in the case of the last good book question, used to create a book display. During Finals Weeks library users are invited to stop at Access Services to make use of crayons and printed coloring sheets as a form of stress relief. With their permission the resultant artwork is then displayed on columns on the first floor and, again, featured in social media.

Another popular activity initiated by Access Services is related to the Campus Read book, which is selected each year by the Boise State president. The Campus Read for 2012 was The Scarlet Macaw, so Access Services bought a stuffed red parrot which student workers hid somewhere in the library with a note for the finder to bring the animal to the Access Services desk. When the finder did so they were rewarded with a small prize. This activity provided a whimsical diversion for not only the students finding the parrot, but also those work-study student workers hiding him, who thought about appropriate places for a parrot, such as the zoology section, and promoted the contest through social media like Instagram.

Access Services staff have been key in the development of relationships with several student groups which have helped further the image of the library as a responsive and collaborative institution dedicated to their success. Examples include the library's interactions with the Associated Students of Boise State University (ASBSU), who repeatedly requested that the library be open longer hours. In response, Albertsons Library ran a pilot program in which two floors of the library were kept open until 2am (rather than closing at the usual midnight) Monday through Thursday for over two weeks. From the data gathered in the pilot, the library was able to present to ASBSU the cost per student for the late nights, helping the students understand why the library had to stick with shorter hours However, Albertsons did offer to have longer hours during dead week (the week before finals) when student use would better justify the costs. Albertsons Library has also allowed ASBSU to use space in the library during finals week to host yoga and other stress relief activities.

Other student groups that have formed continuing relationships with the library staff and space include the Nerds at Night, a group from Boise State's Honor College that meets once a week in the library, featuring their study efforts on a Facebook page. Another student group which promotes its activities in the library through social media is the Delta Sigma Phi fraternity which sets up its "Delta Phort", a corral of study carrels, in a corner of the library during dead and finals weeks. Like the Nerds at Night, the Delta fraternity acts as informal ambassadors for the library, tweeting photos and news of the fort for the duration of its existence.

International students are also acting as informal outreach ambassadors for Albertsons Library, as when the Saudi Students Club posts updates that they're meeting in the library on their Facebook page with pictures of themselves at work in the library. The diversity of student workers at the library may play a part in creating this congenial atmosphere as well as contributing to the outreach efforts of the library through word of mouth within their cultural or language groups. Students who may find it intimidating to approach a librarian sometimes find it easier to approach a peer who speaks the same first language or understands their previous library experiences (or lack thereof). Kettling-Law \& Kille found that the international students manning their library's circulation desk were regularly used as access points to information about the library and the campus generally (2011).

\section{Becoming a Familiar Face}

Albertsons Library has found that attending events where the students are the informants or performers, such as the Undergraduate Research Conference, Summer Research Institute, and Graduate Student 
Research Symposium are excellent opportunities to engage with students and their work. Also, by initiating relationships with those faculty sponsoring or mentoring these research groups, Albertsons Library has come to be seen as a natural partner in supporting the students' research efforts; the library staff is regularly invited to consult or present workshops as part of these research projects. Albertsons librarians find these presentations to be especially effective, as the students are getting research assistance at their precise point of need, which in turn builds student trust in library support of their development as researchers, and information consumers in general. In supporting students in their research, the library fosters their participation in the research and learning communities in the library and campus at large.

Through attendance and active participation in events hosted by non-majority groups, Albertsons staff and faculty are forging relationships with those students who may not traditionally view the library as an ally in their education. Albertsons Library representatives regularly attend such multicultural events as the Middle Eastern lunch hosted by Kuwaiti and Saudi students, the Asian New Year celebration, LGBT information panels, and the Tunnel of Oppression, (an interactive theater experience designed to display oppression of marginalized groups hosted by Multicultural Student Services). Attendance is only the first step in the library's efforts at these events. The library representatives wear name tags and engage wherever possible with the sponsors and other attendees: during question and answer sessions, while standing in line, in casual conversation with the person they're sitting next to, taking any opportunity to introduce themselves and make that connection to the library with the hope of breaking down barriers to library use, whether physical or mental. By actively participating in campus events outside Albertsons, the library faculty and staff become more familiar to their community, enhancing users' perceptions of the library as engaged in campus life and a focal point in the community.

\section{Collaborating for Understanding}

Albertsons Library's outreach efforts also include networking across campus through contributions to faculty working groups, more formal committees, and professional development opportunities. These collaborations may not be traditionally thought of as outreach, but these activities work quite effectively to build the library's understanding of their patrons, while also nurturing the campus community's understanding of the ways in which the library supports their learning, instruction and research. Often these collaborations snowball into additional invitations to contribute to other campus initiatives.

Albertsons Library's head of ScholarWorks (Boise State's institutional repository) \& Data Management, provides one example of how Albertsons librarians have parlayed typical library responsibilities into particularly fruitful partnerships. After responding to research questions from Boise State's Office of Sponsored Programs about metadata and a grant application, this librarian was invited to be part of a campus team exploring data management and the most effective ways to support faculty as they face the challenges of new requirements for data management plans in application for federally funded grants. Through her ongoing contributions to the data management initiative, this librarian has enhanced the library's reputation as a key informant in research on campus.

Additional invitations for collaboration have come to Albertsons Library from the Organizational Performance and Workplace Learning (OPWL) department and Idaho Digital Learning Academy (IDLA), among others. OPWL offers online only graduate programs and their distance students were in need of some support in their research. Albertsons responded to OPWL's request for help with the development of online video modules to assist in the program's orientations. Making the library visible and accessible 
to this ever-growing segment of university campuses is an essential aspect of fostering the learning and research communities beyond the campus.

The Special Collections department at Albertsons has been instrumental in extending the library's outreach efforts to the Boise community at large. By lending items for display at community events, such as Boise's Sesquicentennial celebration, Basque celebrations, and the Fettucine Forum (a lecture series produced by Boise's Department of Arts and History), Special Collections has broadened the audience for the library's archives while creating collaborative relationships that result in further opportunities. Special Collections has also hosted tours for Boise State staff and local elementary schools, effectively building understanding of their mission, as well as their collections. Like Albertsons Library generally, Special Collections has demonstrated responsiveness to its community by running a pilot program of later hours once a week. Once the pilot program proved successful, the department opted to make later hours a regular part of their schedule.

\section{ASSESSMENTS}

The effectiveness of Albertsons Library's grassroots outreach efforts in fostering diverse learning and research communities can be measured in a variety of ways. With its interactivity and measurement tools, social media provides some of the largest body of evidence of the library's outreach effectiveness. Each social media network provides some sort of statistical insight which may be viewed as a measure of outreach success, although, as Steiner concludes, without measurable goals in place when social media strategies are formed, assessing social media success can be difficult (2012). Albertsons Library's earliest forays into social media (Twitter and the blog) were conducted through a desire to establish a more interactive presence online and represent the library as a technically savvy institution in tune with its users, rather than through a delineated strategy or clearly stated goals. Still, the library's robust relationships on most of its social media networks would seem to point to its accomplishments in effectively building a community through its social media presence.

Twitter's Notifications tool gives Albertsons Library immediate proof of interest in what is being posted through notifications on which library tweets are being shared or "favorited." The Notification tool also alerts the library whenever they are mentioned in a tweet such as this one "@BSULibrary I just wanted to say thanks for all the help this year! Best library staff ever!!! See you in the Fall” (@1kplum, 2014, May 14) as have campus staff, "Sometimes I wish I was still an undergrad so I could cram crash @BSULibrary all day/night during dead/finals week. Like zombie party” (@ladufurrena, 2014, May 7). In addition, Twitter has analytics which provide an overview of tweets' effectiveness according to interactivity (Faves, Retweets and Replies) with a measure of how much better than average a tweet performed for interactivity.

Facebook provides an array of useful statistics through its Insights analytical tool; on May 14, 2014, Insights indicated that Albertsons Library's Facebook page had 1.024 likes, a post reach of 13.6K (the number of people who saw any activity from the page including posts, posts by other people, page like ads, mentions, and check-ins), and engagement of 861 (the number of likes, comments and shares) with $1.7 \mathrm{~K}$ post clicks.

Blogger's analytics indicate that Albertsons Library's blog had had more than 90,000 total views of its 661 posts as of May 21, 2014. Blogger's analytics can also break down the statistics by month, so, for 
example, the blog had 2,765 views from April 21-May 21. Blogger analytics also indicate a blog's traffic sources which, for Albertsons Library, include a National Parks Service web page on Robert Limbert (http://www.nps.gov/crmo/historyculture/robert-limbert.htm), which uses photos from Albertsons Library's special collections, an indicator of connection to community beyond the campus. YouTube also provides its own analytics; during April 21-May 20 this year videos on the library's YouTube channel had 1,279 total views.

For an overall picture of social media effectiveness, Albertsons Library uses Klout, which is a mobile app as well as a website that gives social media users a score and rank between 1 and 100 that indicates interactivity. Albertsons Library uses Klout to measure a combination of Facebook, Twitter and Instagram for an average Klout score of 55, which puts the library in the top $20 \%$ of media contributors using Klout. SumAll is a relatively new social media analytical tool which has been tested by Albertsons librarians for an additional overview of the library's social media efforts; although it provides statistics in a clean and useful format, SumAll has proven to be difficult to connect to all the library's social media networks so far. For now, the library will continue to experiment with SumAll and other social media statistical information providers such as Google Analytics and StatCounter. An additional indicator of success in social media use outside of this sort of statistical data was provided by LibraryScienceList. com, which rated Albertsons Library rated number 5 in the Top 100 Most Social Media Friendly Colleges \& Universities for 2013 (2013, April 4).

One shortcoming of grassroots outreach is that its fluid, responsive and spontaneous nature rarely includes formal assessments of the kind acceptable in traditional educational settings. Still, in addition to the extensive social media analytics mentioned previously, there are some notable examples of measures of grassroots outreach success at Albertsons Library. Such examples would include the continued collaborations with student organizations like ASBSU and the Honors College, as well as ongoing partnerships with services supporting students such as International Students Services and the Women's Center. Other invitations for collaboration with campus entities supporting faculty development such as Boise State's Center for Teaching and Learning, and the Office of Sponsored Programs are further indicators of success. Evidence of Albertsons Library's influence on campus is provided in the fact that the stakeholders in these and other university initiatives are regularly seeking out partnerships with the library.

These partnerships extend beyond the university campus, to not only the city of Boise, but also the state of Idaho, as shown in a recent story in the Idaho Statesman, where the author noted that they "relied on our partners at the Boise State Library's Special Collections office." The Idaho Statesman negative collection held in Special Collections at Boise State has also led to additional partnerships with organizations such as Preservation Idaho, as in the website and documentaries for the Boise Architecture Project (2014), and Boise Public Radio, as in Scott Graf's story on the 1959 Boise mudslide (2014).

More locally, the library's inclusion in campus events such as Welcome Week and Act Now provide yet more indicators of its achievements in building a large and diverse community through it outreach efforts. Those organizing campus events regularly request Albertsons Library's marketing support through mention in its social media networks and in its slideshows; recent examples include requests by the Mindfulness, Creativity and Leadership workshop sponsored by the Arts and Humanities Institute, the World of Science and Fiction (a presentation series sponsored by ASBSU and the Gender Studies department), and Jayu, a film festival on North Korea sponsored by the Political Science students' club. Clear evidence of the effectiveness of the computer lab and monitor slideshows was recently provided in response to a slide for Gay Pride Month which promoted the Gay Life Collection held in Special Collections. A student not only noticed the slide, but acted on the information provided, going to the 
Special Collections department in Albertsons Library and requesting access to the collection, noting that she had been unaware of its existence before she saw the slide.

Finally, it should be noted that the accomplishments outlined in this chapter took years from inception to fruition. Albertsons Library's social media accounts were established eight years ago; only in the past few years have they garnered the number of followers and interactivity that might be deemed successful. As these numbers built, so, too, did social media contributors' understanding of which networks were populated by library users, in which networks a library presence would be welcome, and how to establish relationships with users through genuine interactions with Albertsons Library's social media persona.

The library's service orientation was also initiated about eight years ago, and also took years to morph into partnerships and collaborations, creating a foundation for further experimentation, and, of course, future failures. Fear of failure has sometimes stymied grassroots outreach efforts at Albertsons. At times, outreach innovators have had to carefully generate buy-in for new ideas with evidence of community need, best practices at other libraries, or statistical data. By not giving up, these agents of change have helped foster a general feeling of ownership at Albertsons Library, and a dedication to its users that generates ongoing efforts in grassroots outreach and renewed commitment to fostering its learning and communities.

\section{FUTURE DIRECTIONS}

The next big project on Albertsons Library's outreach horizon is the library's 50th Anniversary. Because this celebration includes multiple events and displays coordinated by various groups within the library over the course of the entire year, plans, meetings and budgets are an integral part of the process. However, while these larger events requiring funding or the investment of major manpower must be coordinated in more traditional ways, the library remains open to additional opportunities that may present themselves for the anniversary. By being flexible about how the library's extended celebration will be conducted, the planning committee can integrate its community's ideas and make the celebration as much about the community as the founding of the building.

This flexibility is an important aspect of new outreach initiatives at Albertsons in the form of programming. The library has not hosted any programming for several years; however, with a new dean at the helm, and fresh ideas from new library staff, Albertsons has begun wading into these waters. Recently the library hosted Yarn Bombing as stress relief over dead and finals weeks. The nascent Knitting Club on campus was called on to participate, and regular knitting sessions were conducted near the Starbucks coffee shop in the library to grab the attention of walk-ins. The resultant yarn squares were then used to wrap a column in the library lobby for International Yarn Bombing Day. The event was also coordinated with a library guide on stress relief (http://guides.boisestate.edu/stressrelief) as well as numerous posts throughout the library's social media networks and a book display focused on knitting and other forms of stress relief. A Google Forms survey was administered to participants to garner information to use in-house as support and direction for future programming efforts. Judging by the survey results, creative and informal programming such as Yarn Bombing will likely become an integral addition to Albertsons Library's outreach initiatives.

With programming, surveys may be more regularly relied upon as not only evidence of outreach success in the future at Albertsons, but also to gauge user interest in additional programming and other outreach efforts. Albertsons currently performs LibQUAL+ surveys every two years to provide insight 
into its community's perceptions of the library, but smaller, more focused surveys or focus groups may be just as useful. Along with surveys, Albertsons Library might do a better job of implementing an important resource in its outreach, the students at Boise State, to foster the growth of a community that truly reflects the interests of its users. Only recently have student contributions to social media been allowed, which, aside from their work at the circulation desk, pretty much defines most of their contributions to the library's outreach efforts at this time. With the establishment of a student advisory group for the library, or an even better developed relationship with one of the standing student organizations, such as ASBSU, Albertsons could tap in directly to the needs of one of the largest components of their community.

\section{CONCLUSION}

This chapter has provided a broad overview of how an academic library may successfully create a brand which speaks to its users and fosters their interaction with library spaces, services, resources and people, without investing a large amount of money. It also looked at how, in supporting the outreach efforts of a diverse array of library staff and students, Albertsons Library has effectively reached an equally diverse group of users across the campus and community. These efforts have not required extensive administration or control. However, they have required trust in the professionalism of its contributors, creativity, a bit of training or guidance, and an understanding of the mission of the library and how outreach contributes to the fulfillment of that mission.

Although Albertsons Library has not featured traditional programming in recent years, it has established itself as the center of the Boise State learning and research communities in reputation as well as location. By being active at campus events hosted by faculty and students, Albertsons Library has become known for collaboration and innovation. By being flexible, Albertsons Library has been able to take advantage of opportunities to interact meaningfully and authentically with its community. These characteristics all contribute to the continuing development of the library's positive reputation and its integral position at Boise State University. They are characteristics that any academic library can foster by supporting the participation in outreach efforts of all at the library, regardless of department or job

responsibilities, by establishing a library brand from which to operate, and by regularly interacting with its users outside of the library.

\section{ACKNOWLEDGMENT}

The author would like to thank Ash Whitwell for ideas, editing, and resources. I'm also grateful to other key informants for this chapter including (but not limited to): Mary Aagard, Michelle Armstrong, Tracy Bicknell-Holmes, Deana Brown, Memo Cordova, Carrie Moore, Julia Stringfellow, Amy Vecchione.

\section{REFERENCES}

Aagard, M., Armstrong, M., Cooper, P., \& Nuxoll, R. (2013). iPads for all: Experiencing the unexpected. College \& Research Libraries News, 74(1), 18-20. Retrieved from http://crln.acrl.org/content/74/1/18.full 
Baldwin, D. (1996). The academic librarian's guide to human resources: Employer rights and responsibilities. Santa Barbara, CA: Librarians Unlimited/Linworth.

Barber, P. (2014, February 10). Contagious marketing: How libraries can get more word-of-mouth buzz. [WebLog Post] Retrieved from http://www.americanlibrariesmagazine.org/article/contagious-marketing

Boise Architecture Project. (2014). Retrieved from http://boisearchitecture.org/videos.php

Boise State University. (2013). Facts \& figures, 2013-2014. Retrieved from http://news.boisestate.edu/ wp-content/blogs.dir/1/files/2011/08/facts-figures-2014.pdf

Brinkman, S., \& Weinstein-Yates, F. W. (2008). Promoting partnership: Campus and community collaboration through cultural events. College \& Research Libraries News, 69(3), 147-150. Retrieved from http://crln.acrl.org/content/69/3/147.full.pdf

Carter, T. M., \& Seaman, P. (2011). The management and support of outreach in academic libraries. Reference and User Services Quarterly, 51(2), 163-171. http://search.proquest.com/docview/9128132 76 ?accountid=9649 doi:10.5860/rusq.51n2.163

Chu, S. K. W., \& Du, H. S. (2013). Social networking tools for academic libraries. Journal of Librarianship and Information Science, 45(1), 64-75. http://lib-edpsy.alzahra.ac.ir/documents/10157/39868/64. full.pdf doi:10.1177/0961000611434361

Cooper, P., Glackin, B., \& Moody, M. (2011). 55,000 ways to say yes: Customer-driven acquisitions and more! Retrieved from http://works.bepress.com/marilyn_moody/19/

Crawford, K. (2009). Following you: Disciplines of listening in social media. Continuum (Perth), 23(4), 525-535. doi:10.1080/10304310903003270

Cummings, L. U. (2007). Bursting out of the box: Outreach to the millennial generation through student services programs. RSR. Reference Services Review, 35(2), 285-295. doi:10.1108/00907320710749191

Duke, L. M., \& Tucker, T. (2007). How to develop a marketing plan for an academic library. Technical Services Quarterly, 25(1), 51-68. doi:10.1300/J124v25n01_05

Facebook Insights. (2014, May 14) Retrieved from https://www.facebook.com/albertsonslibrary?sk=i nsights\&section $=$ navOverview

Gaf, S. (2014, April 18). How Boise's 1950 mudslide led to protections for city's foothills. Boise Public Radio. Retrieved from http://boisestatepublicradio.org/post/how-boises-1959-mudslide-led-lastingprotections-citys-foothills

Hallmark, E. K., Schwartz, L., \& Roy, L. (2007). Developing a long-range and outreach plan for your academic library: The need for a marketing outreach plan. College \& Research Libraries News, 68(2), 92-95. Retrieved from http://crln.acrl.org/content/68/2/92.full.pdf

Hernas, P., \& Karas, T. (2008). Campus partnership in small academic libraries: Challenges and rewards. In J. McNeil Hurlbert (Ed.), Defining Relevancy (pp. 131-145). Westport, CT: Libraries Unlimited. 
Hickock, J. (2011). Knowing their background first: Understanding prior library experiences of international students. In P. Jackson \& P. Sullivan (Eds.), International students and academic libraries: Initiatives for success (pp. 1-18). Chicago: Association of College and Research Libraries.

Jaguszewski, J. M., \& Williams, K. (2013). New roles for new times: Transforming liaison roles in research libraries. Washington, D.C.: Association of Research Libraries; Retrieved from http://www. arl.org/publications-resources/2893-new-roles-for-new-times-transforming-liaison-roles-in-researchlibraries\#.U5CRo_ldUoM

Jaszewski, J. (2014, June 1). Eyes on Idaho: The best of Statesman photojournalism. Idaho Statesman. Retrieved from http://www.idahostatesman.com/2014/06/01/3212932/eyes-on-idahothe-best-ofstatesman.html

Kaarst-Brown, M. L., Nicholson, S., Von Dran, G. M., \& Stanton, J. M. (2004). Organizational cultures of libraries as a strategic resource. Retrieved from https://www.ideals.illinois.edu/bitstream/ handle/2142/1722/Kaarst-Brown3353.pdf

Kettling Law, E., \& Kille, N. (2011). Creating research ambassadors: Expanding the role of international students. In P. Jackson \& P. Sullivan (Eds.), International students and academic libraries: Initiatives for success (pp. 45-68). Chicago: Association of College and Research Libraries.

Kirk, D. J. (2011). Using social media to build brand loyalty: Insights from the designer shoe industry. Drake Management Review, 1(1). 37-41. Retrieved from http://faculty.cbpa.drake.edu/dmr/0101/ DMR010107R.pdf

Kranich, N., Lotts, M., \& Springs, G. (2014). The promise of academic libraries: Turning outward to transform campus communities. College \& Research Libraries News, 75(4), 182-186. Retrieved from http://crln.acrl.org/content/75/4/182.short

@ ladufurrena (Dufurrena, L.A.). (2014, May 7) Sometimes I wish I was still an undergrad so I could cram crash @BSULibrary all day/night during dead/finals week. Like zombie party. [Twitter Post Retrieved from https://twitter.com/i/notifications

Lazzarro, A. E., Mills, S., Garrard, T., Ferguson, E., Watson, M., \& Ellenwood, D. (2014). Cultural competency on campus: Applying ACRL's Diversity Standards. College \& Research Libraries News, 75(6), 332-335. Retrieved from http://crln.acrl.org/content/75/6/332.short

Lenhart, A., Purcell, K., Smith, A., \& Zickuhr, K. (2010). Social media \& mobile internet use among teens and young adults. Pew Internet \& American Life Project. Retrieved from http://files.eric.ed.gov/ fulltext/ED525056.pdf

LibraryScienceList.com. (2013, April 4). Top 100 most social media friendly colleges and universities. Retrieved from http://librarysciencelist.com/100-most-social-media-friendly-college-university-libraries/ @ lkplum (Plummer, L.). (2014, May 14). @BSULibrary I just wanted to say thanks for all the help this year! Best library staff ever!!! See you in the Fall. [Twitter Post] Retrieved from https://twitter.com/i/ notifications 
Lockhart, J., \& Majal, S. (2012). The effect of library staff training and development on the user experience: A case study at the Cape Peninsula University of Technology (CPUT). 2012 IATUL Proceedings. Retrieved from http://tinyurl.com/nnlwglq

Mestre, L. S. (2010). Librarians working with diverse populations: What impact does cultural competency training have on their efforts? Journal of Academic Librarianship, 36(6), 479-488. doi:10.1016/j. acalib.2010.08.003

Meulemans, Y. N., \& Carr, A. (2013). Not at your service: Building genuine faculty-librarian partnerships. RSR. Reference Services Review, 41(1), 80-90. http://ils.unc.edu/courses/2013_fall/inls502_001/ Readings/Meulemans.pdf doi:10.1108/00907321311300893

Monroe-Gulick, A., O’Brien, M., \& White, G. W. (2013). Librarians as partners: Moving from research supporters to research partners. Retrieved from http://www.ala.org/acrl/sites/ala.org.acrl/files/content/ conferences/confsandpreconfs/2013/papers/GulickOBrienWhite_Librarians.pdf

Montiel Overall, P. (2009). Cultural competence: A conceptual framework for library and information science professionals. The Library Quarterly, 79(2), 175-204. doi:10.1086/597080

Rudin, P. (2008). No fixed address: The evolution of outreach library services on university campuses. The Reference Librarian, 49(1), 55-75. doi:10.1080/02763870802103761

Salomon, D. (2013). Moving on from Facebook: Using Instagram to connect with undergraduates and engage in teaching and learning. College \& Research Libraries News, 74(8), 408-412. Retrieved from http://crln.acrl.org/content/74/8/408.full

Singh, R. (2004). Branding in library and information context: The role of marketing culture. Information Services \& Use, 24(2), 93-98. Retrieved from http://web.a.ebscohost.com/ehost/pdfviewer/ pdfviewer?sid=83f194df-2cae-4295-8b7a-e99777ee5fb2\%40sessionmgr4005\&vid=2\&hid=4209

Solomon, L. (2011). Doing Social Media So It Matters: A Librarian's Guide. Chicago: American Library Association.

Stebelman, S., Siggins, J., Nutty, D., \& Long, C. (1999). Improving library relations with the faculty and university administrators: The role of the faculty outreach librarian. College \& Research Libraries, 60(2), 121-130. http://crl.acrl.org/content/60/2/121.full.pdf doi:10.5860/crl.60.2.121

Steiner, S. K. (2012). Strategic planning for social media in libraries. Chicago: ALA TechSource.

United States Census Bureau. (2010). State \& county quick facts. Retrieved from http://quickfacts.census. gov/qfd/states/16/1608830.html

Virtue, A., \& Esparza, L. (2013). Faculty reconnect: Creative outreach to keep faculty up-to-date in the digital whirlwind. College \& Research Libraries News, 74(2), 80-99. Retrieved from http://crln.acrl. org/content/74/2/80.full.pdf

Watson, L. (2010). The future of the library as a place of learning: A personal perspective. New Review of Academic Librarianship, 16(1), 45-56. doi:10.1080/13614530903574637 
Wilcox, E., \& Yew, B. C. (2013). Fostering a sticky relationship with academic library users. Library Management, 34(3), 175-187. doi:10.1108/01435121311310879

\section{ADDITIONAL READING}

Abdullahi, I. (2007). Diversity and intercultural issues in library and information science (LIS) education. New Library World, 108(9/10), 453-459. http://www.emeraldinsight.com/journals.htm?articleid=1628159 doi:10.1108/03074800710823980

Aguilar, P., Keating, K., Schadl, S., \& Van Reenen, J. (2011). Reference as outreach: Meeting users where they are. Journal of Library Administration, 51(4), 343-358. doi:10.1080/01930826.2011.556958

Ansberry, D., \& Snavely, L. (2011). Engaging international students in academic library initiatives for their peers. In P. Jackson \& P. Sullivan (Eds.), International students and academic libraries: Initiatives for success (pp. 69-82). Chicago: Association of College and Research Libraries.

Burkhardt, A. (2010). Social media: A guide for college and university libraries. College \& Research Libraries News, 71(1), 10-24. Retrieved from http://crlnews.highwire.org/content/71/1/10.full

Carscaddon, L., \& Chapman, K. (2013). Twitter as a marketing tool for libraries. In B. C. Thomsett-Scott (Ed.), Marketing with Social Media: A LITA Guide. Chicago: American Library Association.

Caspers, J. S. (2008). Outreach to distance learners: When the distance education instructor sends students to the library, where do they go? The Reference Librarian, 32(67-68), 299-311. doi:10.1300/ J120v32n67_21

Courtney, N. (2009). Academic library outreach: beyond the campus walls. University of Michigan: Libraries Unlimited.

Crowe, K. (2010). Student affairs connection: Promoting the library through co-curricular activities. Collaborative Librarianship, 2(3). 154-158. Retrieved from http://www.collaborativelibrarianship.org/

Debra, K. G., \& Tassel, V. (2000). Expanding the learning community: An academic library outreach program to high schools. The Reference Librarian, 32(67-68), 161-173. doi:10.1300/J120v32n67_12

Delaney, G., \& Bates, J. (2014). Envisioning the academic library: A reflection on roles, relevancy and relationships. New Review of Academic Librarianship. Retrieved from http://eprints.ulster.ac.uk/29362/1/ Delaney_\%26_Bates_-_Author_Accepted_Manuscript_April_2014.pdf

Dickson, A., \& Holley, R. P. (2010). Social networking in academic libraries: The possibilities and the concerns. New Library World, 111(11/12), 468-479. doi:10.1108/03074801011094840

Fabian, C. A., D'aniello, C., Tysick, C., \& Morin, M. (2004). Multiple models for library outreach initiatives. The Reference Librarian, 39(82), 39-55. doi:10.1300/J120v39n82_04

Fernandez, J. (2009). A SWOT analysis for social media in libraries. Online, 33(5), 35-37. 
Gibbons, S. (2007). The academic library and the net gen student: Making the connections. Chicago: American Library Association.

Glazer, H. (2009). Clever outreach or costly diversion? An academic library evaluates its Facebook experience. College \& Research Libraries News, 70(1), 11-19. Retrieved from http://crln.acrl.org/ content/70/1/11

Harley, B., Dreger, M., \& Knobloch, P. (2001). The postmodern condition: Students, the web, and academic library services. RSR. Reference Services Review, 29(1), 23-32. http://search.proquest.com/doc view/200544111 ?accountid=9649 doi:10.1108/00907320110366750

Hensley, M. K., \& Love, E. (2011). A multifaceted model of outreach and instruction for international students. In P. Jackson \& P. Sullivan (Eds.), International students and academic libraries: Initiatives for success (pp. 115-134). Chicago: Association of College and Research Libraries.

Kaur, K. (2009). Marketing the academic library on the web. Library Management, 30(6/7), 454-468. doi:10.1108/01435120910982140

Kenneway, M. (2006). Branding for libraries: Communicating your value to increase reader awareness and usage of the library service. Serials: The Journal for the Serials Community, 19(2), 120-126. doi: $10.1629 / 19120$

King, D. L. (2012). Face2face: Using Facebook, Twitter, and other social media tools to create great customer connections. Chicago: Information Today, Inc.

Knapp, J. A., Snavely, L., \& Klimczyk, L. (2012). Speaking up: Empowering individuals to promote tolerance in the academic library. Library Leadership \& Management, 26(1). Retrieved from http:// journals.tdl.org/llm/index.php/llm/article/viewFile/5508/5849

Kraemer, E. W., Keyse, D. J., \& Lombardo, S. V. (2004). Beyond these walls: Building a library outreach program at Oakland University. The Reference Librarian, 39(82), 5-17. https://our.oakland.edu/ bitstream/handle/10323/2610/buildinglibraryoutreach\%20final\%20draft.pdf?sequence=1 doi:10.1300/ J120v39n82_02

Love, E., \& Edwards, M. B. (2009). Forging inroads between libraries and academic, multicultural and student services. RSR. Reference Services Review, 37(1), 20-29. doi:10.1108/00907320910934968

Martin, J. A., Reaume, K. M., Reeves, E. M., \& Wright, R. D. (2012). Relationship building with students and instructors of ESL: Bridging the gap for library instruction and services. RSR. Reference Services Review, 40(3), 352-367. doi:10.1108/00907321211254634

Mathews, B. S. (2009). Marketing today's academic library: a bold new approach to communicating with students. Chicago: American Library Association.

Mi, J., \& Nesta, F. (2006). Marketing library services to the Net generation. Library Management, 27(6), 411-422. doi:10.1108/01435120610702404

Moore, C., Stringfellow, J., Vecchione, A., \& Cordova, M. (2014) Using blogs to market library services and resources. Thomsett-Scott, B.C. (ed.) Marketing with Social Media. (pp.115-130). Chicago: ALA TechSource. 
$\mathrm{Mu}, \mathrm{C}$. (2007). Marketing academic library resources and information services to international students from Asia. RSR. Reference Services Review, 34(4), 571-583. doi:10.1108/00907320710838390

Mundava, M., \& Gray,L. (2008). Meeting them where they are: Marketing to international student populations in U.S. academic libraries. Technical Services Quarterly, 25(3), 35-48. doi:10.1080/07317130802128627

Neal, D. R. (Ed.). (2012). Social media for academics: A practical guide. Oxford: Chandos Publishing Ltd. doi:10.1533/9781780633190

Polger, M. A., \& Okamoto, K. (2013). Who's spinning the library? Responsibilities of academic librarians who promote. Library Management, 34(3), 236-253. doi:10.1108/01435121311310914

Puente, M. A., Gray, L., \& Agnew, S. (2009). The expanding library wall: Outreach to the University of Tennessee's multicultural/international student population. RSR. Reference Services Review, 37(1), 30-43. doi:10.1108/00907320910934977

Schneider, T. (2004). Outreach: Why, how and who? Academic libraries and their involvement in the community. The Reference Librarian, 39(82), 199-213. doi:10.1300/J120v39n82_13

Switzer, A. T. (2008). Redefining diversity: Creating an inclusive academic library through diversity initiatives. College \& Undergraduate Libraries, 15(3), 280-300. doi:10.1080/10691310802258182

Theodore-Shusta, E., \& Dawson-Andoh, A. (2014). Engaging the campus community in conversations on diversity: Ohio University Libraries' Culture Showcase Series. College \& Research Libraries News, 6(75), 328-331. Retrieved from http://crln.acrl.org/content/75/6/328.short

Ury, C. J., Meldrem, J. A., \& Johnson, C. V. (2000). Academic library outreach through faculty partnerships and web-based research aids. The Reference Librarian,32(67-68), 243-256. doi:10.1300/J120v32n67_17

Walter, S. (2005). Moving beyond collections: Academic library outreach to multicultural student centers. RSR. Reference Services Review, 33(4), 438-458. http://kuscholarworks.ku.edu/dspace/bitstream/1808/410/3/Walter_RSR.pdf?origin=publicationDetail doi:10.1108/00907320510631562

Walton, G. (2008). Theory, research, and practice in library management 5: Branding. Library Management, 29(8/9), 770-776. doi:10.1108/01435120810917369

Winston, M. D., \& Li, H. (2000). Managing diversity in liberal arts college libraries. College \& Research Libraries, 61(3), 205-215. http://crl.acrl.org/content/61/3/205.full.pdf doi:10.5860/crl.61.3.205

Woodward, J. A. (2009). Creating the customer-driven academic library. Chicago: American Library Association. 


\section{KEY TERMS AND DEFINITIONS}

Brand Loyalty: Connection to the perceived characteristics of a product or institution which nurtures continued consumption of the product or relationship with the institution.

Branding: Establishing a subconscious association between a product or institution and certain characteristics.

Cross Cultural Competence: Ability to act effectively when interacting with cultures outside one's own.

Grassroots: Describing actions initiated from the lower level of a power structure or institution.

Inclusive: Not only welcoming, but considerate of all associated with a place or activity.

Interactive: Fostering mutual participation in action between two people or a person and technology.

Outreach: Any activity, display or event which fosters either interaction with library staff, services or resources or connection to the library brand. 